\title{
IMPROVING SPEAKING ABILITY THROUGH SMALL GROUPS DISCUSSION FOR THE EIGHTH YEAR STUDENTS OF SMPN 2 SALUPUTTI IN TANA TORAJA
}

\author{
Roni La'biran \\ Program Studi Pendidikan Bahasa Inggris \\ Universitas Kristen Indonesia Toraja \\ ronilabiran@yahoo.co.id
}

\begin{abstract}
The objective of the study is to know the small groups discussion can improve the students' speaking ability. In order to achieve the objective of this study, the writer designed an experimental method using pre-test and post- test. The population of this study was the eighth year students of Junior High School of SMPN 2 Saluputti. The sample of this study was the eight year students in academic year 2015/2016. The number of the students was 16 students. There were four meetings during the experiment. Before the experiment was conducted, the students were given a pre-test. At the end of the experiment, the students were given a post- test. The result of this study revealed that, the post- test scores were better than the pre-test scores. It could be seen by comparing their means. The mean score of the pre-test was 22.8, while the mean of the post test was 78.2. It shows that the mean score of the post test is greater than the pre test. The difference between pre test and post test was 55.3. In line with the result, the writer concludes that the Small Groups Discussion strategy is one of the effective strategies as to increase the activity and student learning outcomes in speaking subject. In teaching and learning activities teachers are expected to make cooperative learning as an alternative type of Small Groups Discussion in speaking subject to increase the activity and student learning outcomes, especially when teaching speaking to eighth year students of junior high school.
\end{abstract}

Keyword: Small Group Discussion, Speaking

\begin{abstract}
Abstrak
Tujuan dari penelitian ini adalah untuk mengetahui apakah Diskusi Kelompok Kecil dapat meningkatkan kemampuan berbicara siswa. Untuk mencapai tujuan penelitian ini, penulis merancang metode eksperimen dengan menggunakan pre-test dan post-test. Populasi penelitian ini adalah siswa kelas VIII SMPN 2 Saluputti. Sampel penelitian ini adalah delapan tahun siswa pada tahun ajaran 2015/2016. Jumlah siswa adalah 16 siswa. Ada empat pertemuan selama percobaan. Sebelum percobaan dilakukan, siswa diberi pre-test. Pada akhir percobaan, siswa diberi post-tes. Hasil penelitian ini menunjukkan bahwa nilai post-test lebih baik daripada nilai pre-test. Skor rata-rata pre-test adalah 22,8 , sedangkan dari post test adalah 78,2. Ini menunjukkan bahwa nilai rata-rata post test lebih besar daripada pre test. Perbedaan antara pre test dan post test adalah 55,3. Sejalan dengan hasilnya, penulis berkesimpulan bahwa strategi Diskusi Kelompok Kecil merupakan salah satu strategi efektif untuk meningkatkan aktivitas dan hasil belajar siswa dalam mata pelajaran berbicara. Dalam kegiatan belajar mengajar guru diharapkan dapat melakukan pembelajaran kooperatif sebagai alternatif jenis Diskusi Kelompok Kecil dalam berbicara yang dapat meningkatkan aktivitas dan hasil belajar siswa, terutama saat mengajar berbicara kepada siswa kelas VIII SMP.
\end{abstract}

Kata Kunci: Diskusi Kelompok Kecil, Berbicara

\section{INTRODUCTION}

Language is a tool of communication used by human beings to communicate with each other, express feelings, ideas, and emotions in society. Living in society 
human beings are expected to use language to communicate as well as possible. So, without the ability to communicate, we would live in isolation, separate each other.

Communication is the transformation of meaning from one person to another by using signs or symbols. A sign or symbol is transmitted from a sender to a receiver. Moreover, communication deals with the process of encoding and decoding that the message is transferred from the speaker to the hearer. The speaker wants the receptor to receive the message as complete as he conveys. So, he needs a certain ability to transfer the message. This ability is generally known as speaking ability. The speaking ability means the speakers proficiency or ability to communicate or to choose and the use the language appropriately in order the receptor can understand and able to give respond that the message is understood.

English as a foreign language is learned from primary school up to university level in Indonesia. English involves four skills namely speaking, listening, reading, and writing. Speaking is one of important aspect that can influence the students to increase their pronunciation and mainly the goals of the teaching English in Indonesia are to enable the students to use English communication and specially use in daily activities. The fact right now that most of the students are less activated to speak moreover, speaking class tends to monotonous and uninteresting. By this, English teacher has to be more creative in choosing the material and can make speaking class exciting enjoy.

In teaching and learning process, the comprehension toward to speaking material shows that the majority of students are not competent English well. The techniques English teaching influences the students' success, so the teacher of English must select suitable method and also the material to teach.

Speaking is very important because the interaction the listener and speaker as the main factors to determine teaching speaking successfully. An act communication through speaking commonly performed in face to face interaction and occurs as part of dialogues or rather forms a verbal exchange.

Teachers must use good strategy to make the students more effective to study. One of the teaching strategies used in learning teaching process is groups discussion. It means that two or more students interaction each other, discuss together, and work together by study for getting the result from side knowledge as skill exchange to ideal attitude and grade.

To overcome the students' difficulties in learning English especially speaking, a teacher must be able to choose appropriate technique or method to be applied in their teaching. There are many ways to develop students' speaking ability, some of them are dialogue technique, role-play technique, question and answer, community language learning, retelling exercise, games, group discussion, etc.

Every student has different capability to accept the material that is explained by the teacher. In groups discussion the students should be work together to finish their assignment and solve the problem. The students who have good speaking hoped can help his friends who have less- speaking of less accept the material that explained by the teacher. 
The small group discussion is one of teaching strategy for the teacher and learning strategy for the students. It is more effective because it can make the students more active in discussion because they much time to express their ideas.

Concerning the background above, the researcher is interested to conduct a research under the title "Improving Speaking Ability through Small Groups Discussion of the Eighth Year Students of Junior High School (SMPN 2) Saluputti. In Tana Toraja.

\section{REVIEW OF RELATED LITERATURE}

\section{a. Speaking}

Speaking skill is the one of the four major skills that seems to be a priority one. According to Harris (1969:81) states "Speaking is a complex skill requiring the stimulations use of a number of different abilities which often develop at different rates." Thus, speaking is an integral part of English language as other language. Lado (1961:240) states "Speaking is the ability to express one self in life situation or the ability to converse or to express sequence of ideas fluently." The definition above shows that, speaking is the ability to express ideas, opinions, and feeling.

Speaking is considered as one of the difficult subjects, as Chastain (1976:334) states "Learning to speak is more difficult than learning to understand spoken language." Means that even if the listener can understand or to get the point of what is said, it does not mean that the listener can speak the language or communicate with it.

Speaking takes place in communication which involves more than one person It requires mutual understanding and interaction between the speakers themselves. The process of understanding involves some aspects for example to know words, sound, intonation, stress, production as well as structural patterns.

Based on the above definitions the researcher says that speaking is the way to say words, the act of utterance, vocal expression, and able to communicate in specified language. Speaking is described as the ability to express oneself in life situation or the ability to report acts or situation in phrase, word, or ability to cover or to express a sequence of ideas fluently.

There are some elements of speaking as Jeremy (2004:269) states "Among the elements necessary for spoken production (as opposed to the production of practice examples in language drills, for example, are the following:

- Connected speech

Effective speaker of English need to be able not only to produce the individual phonemes of English (as in saying I would have gone) but also to use fluent "connected speech" (as in I'd've gone). In connected speech sounds are modified (assimilation), omitted (elision), added (linking), or weakened (through constructions and stress patterning). It is for this reason that we should involve their connected speech.

- Expressive devices

Native speaker of English changes the pitch and stress of particular parts of utterances, vary volume and speech, and slow by other physical and non-verbal 
(paralinguistic) means how they are feeling (especially in face to face interaction). They use of this devices to contributes to the ability to convey meanings. They allow the extra expression of emotion and intensity. Students should be able to deploy at least some of such suprasegmental features and devices in the same way if they are to be fully effective communicators.

- Lexis and Grammar

Spontaneous speech mark by the use of a number of common lexical phrases, especially in the performance of certain language functions. Teachers should therefore supply a variety of phrases for different functions such as agreeing or disagreeing, expressing surprise, shock, or approval.

Where students are involved in specific speaking context such as a job interview, we can prime them, in the same way, with certain useful phrases which they produce at various stages of an interaction.

- Negotiation language

Effective speaking benefits from the negotiatory language we use to seek clarification and to show the structure of what we are saying."

\section{b. Small Group Discussion}

Longman New Universal Dictionary (1982:442) states "Group is a number of individual or objects assembled together having the same unifying relationship." By dividing the class into groups the proportion of each student's responsibility to the group increases dramatically. It is possible for students to help one another and learn from one another. As what Freeman (1986:132) states.

"The necessary practice is thought to be most successful when students are engaged in the meaningful exchange of information rather than repeating a teacher's model. Learners are thus encouraged to be creative and communicative with the language often doing so in small group activities in which they can practice communication and learn from one another."

The statement also indicates the importance and the effectiveness of group discussion. Group discussion is a method of a language teaching in which the teachers divides a class into small groups. Each group may consist of four or six students.

The purpose of dividing the class into small groups is to provide the students the opportunities to use their language. In small groups, the students sit together, facing one another and talk freely based on the problem. They sit in a circle discussing the problem that should be solved. This situation creates free communication in which the students use the language freely in the classroom without feeling shy. Rocks (1981:7) states "The class is divided into small group discussion each of which discussion, analyses, and eventually solves the problem, these problems work best when the discussion group have form four to six students." Thus, it can be concluded that the small group with the members of the students around four or six can give maximum opportunity to students to participate in an activity or in discussion activity. 
Pulston (1976:67) states "Most of the problem solving activities involve group work." Thus, it is reasonable to say that the activities as such give more challenge to speaking. Furthermore, Simon (1972:209) described that

\footnotetext{
"Most of the activities require the learners to solve some kinds of problem. In solving the problem in a cooperative way, the learners imply a whole range of their ideas, attitudes, values and beliefs. This challenges them to be flexible and creative in their use of language."
}

The quotation above shows the importance of group discussion to improve students' speaking ability in the classroom. Group discussion can give the students opportunities to speak freely without feeling shy. It can have a better influence on the students' speaking.

\section{c. Organizing Small Group Discussion}

In conducting a small group discussion, there are some aspects that should be taken into account seriously by the teacher. The first aspect is the student's factor, the second is the classroom, and the third is the teacher's role in doing the discussion. The success of small group discussion depends on how well those aspects are organized.

Most important, during the discussion the teacher should assume the role of consultant who is always available as a resources person or advisor for whatever contingency might arise. In discussion, the teacher acts as the servant that the master of the group. Thus, the teacher's role in the activity and the students' activity too. The teacher should move from group joining the discussion when necessary and helping when it is needed.

\section{d. Grouping}

Dividing a large class into group can be done many ways. Rory McGreal (1989:68) states "Students can be divided according to much character. The most are random sample ability, friendship, and mixed- ability."

Random sample grouping is a technique of grouping students according to their seat. When the teacher divides the students into groups of four students, he or she could easily group those who sit in front of the class into one or two groups up to students who sit at the back seat.

In ability grouping, students are grouped according to their ability levels. This grouping occurs with regarding to the difference of students individually such as interest and levels of ability.

Friendship grouping is away of grouping students that they are free to make their own groups. They will gather their friends who have a close relation with them. This conditions leads to the formation groups of different size. One group may have more members than the others. The students having close relations will work actively in their groups. In contrast, for those who have no good relation less might be passive.

This group shows a strong tendency for students who have the same interest to form themselves into one group. Therefore, friendship grouping has a great similarity with the interest way of grouping because both have the same purpose in which the teacher let his students form their own group. 
Another way of grouping students is mixed-ability. Mixed ability is set up by teacher in order to avoid a superior groups and inferior groups in large class. Besides, it is also intended to get the effect that the weak students can learn a great deal from better students when they work together. Furthermore, Byrne (1980:175) states "The group should be formed by teacher and should include of mixed-ability, on the principle that they will help one another in various ways."

In this research the researcher will use mixed ability grouping because it gathers good and weak students staying in one group. In such grouping, the teacher's responsibility can be shared with the students in which good students can help the weak ones.

\section{METHOD OF THE RESEARCH}

This research was conducted at SMPN 2 Saluputi. It was located on Jln. Poros Rembon, Saluputti District, Tana Toraja. Data sources in this research consist of primary sources by giving oral test and secondary sources by going to library, read some books, and research information from website that related with in this title.

The population of the research was the eighth year students of SMPN 2 Saluputti in academic year 2015/2016. The number of population was about one hundred and twenty-four students and scattered in four classes. The sample was taken by using random sampling technique. Each class was taken four students as the sample of the research, the number of respondents was sixteen students.

The instruments of the research were the oral test. The test consisted of two types of test; they were pre- test and post- test. The pre- test was the speaking test given before treatment. In this test, the students talking about the topic in the class. The post- test was a speaking test based on small groups discussion.

\section{FINDINGS}

The results described from 16 students was various. Their speaking ability had been measured on the rating criteria provided as standard. Then, each score of data was collected and analyzed.

a. The students' score in Pre-test

Table 1: The students`score in pre-test.

\begin{tabular}{|c|c|c|c|c|c|c||}
\hline $\begin{array}{c}\text { NUMBE } \\
\text { R OF } \\
\text { STUDE } \\
\text { NTS }\end{array}$ & $\begin{array}{c}\text { ACCURA } \\
\text { CY }\end{array}$ & $\begin{array}{c}\text { FLUEN } \\
\text { CY }\end{array}$ & $\begin{array}{c}\text { COMPREHEN } \\
\text { SION }\end{array}$ & $\begin{array}{c}\text { TOTA } \\
\text { L }\end{array}$ & $\begin{array}{c}\text { STUDEN } \\
\text { TS } \\
\text { SCORE }\end{array}$ & $\begin{array}{c}\text { SCORE } \\
\text { CLASSIFICA } \\
\text { TION }\end{array}$ \\
\hline 1 & 1 & 1 & 1 & 3 & 16.6 & Very Poor \\
\hline 2 & 1 & 2 & 2 & 5 & 27.7 & Very Poor \\
\hline 3 & 1 & 1 & 2 & 4 & 22.2 & Very Poor \\
\hline
\end{tabular}




\begin{tabular}{|c|c|c|c|c|c|c||}
\hline 4 & 1 & 2 & 2 & 5 & 27.7 & Very Poor \\
\hline 5 & 1 & 2 & 1 & 4 & 22.2 & Very Poor \\
\hline 6 & 1 & 1 & 2 & 4 & 22.2 & Very Poor \\
\hline 7 & 1 & 1 & 1 & 3 & 16.6 & Very Poor \\
\hline 8 & 1 & 1 & 2 & 4 & 22.2 & Very Poor \\
\hline 9 & 1 & 2 & 1 & 4 & 22.2 & Very Poor \\
\hline 10 & 1 & 2 & 2 & 5 & 27.7 & Very Poor \\
\hline 11 & 1 & 1 & 2 & 4 & 22.2 & Very Poor \\
\hline 12 & 1 & 1 & 2 & 4 & 22.2 & Very Poor \\
\hline 13 & 1 & 1 & 2 & 4 & 22.2 & Very Poor \\
\hline 14 & 2 & 1 & 1 & 4 & 22.2 & Very Poor \\
\hline 15 & 2 & 1 & 2 & 5 & 27.7 & Very Poor \\
\hline Total & $\mathbf{1 8}$ & $\mathbf{2 1}$ & $\mathbf{2 7}$ & $\mathbf{6 6}$ & $\mathbf{3 6 6}$ & \\
\hline \hline
\end{tabular}

Source : SMPN 2 Saluputti

Table 1 above shows that the total score of students in pre-test was 66 and their total mean score is 366 . To find out the mean score of speaking ability of students. The following formula was applied:

$$
\begin{aligned}
& \quad \bar{X}=\frac{\sum X}{n} \\
& \quad \text { Where: } \\
& \sum x=366 \\
& \mathrm{~N}=16 \\
& X=\frac{\cdots}{\cdots} \\
& X=22.8
\end{aligned}
$$


students' mean score was 22.8

Table 2: The classification, frequency, and percentage of the students' score in pre- test

\begin{tabular}{|c|c|c|c|c|}
\hline Number & Classification & Score & Frequency & Percentage(\%) \\
\hline 1 & Very Good & $85-100$ & - & - \\
2 & Good & $75-84$ & - & - \\
3 & Fair & $65-74$ & - & - \\
4 & Poor & $54-64$ & - & 100 \\
5 & Very Poor & $0-54$ & 16 & $\mathbf{1 0 0}$ \\
\hline
\end{tabular}

Table above shows that there were no students $0 \%$ who got "very good", "good", "fair", and "poor" score classification. There were 16 or $100 \%$ students classified as "very poor" score. That means all of the students $(100 \%)$ classified as very poor classification.

b. The students' score in Post- test

Table 3: The students' score in post- test.

\begin{tabular}{|c|c|c|c|c|c|c||}
\hline $\begin{array}{c}\text { NUMB } \\
\text { ER OF } \\
\text { STUDE } \\
\text { NTS }\end{array}$ & $\begin{array}{c}\text { ACCURA } \\
\text { CY }\end{array}$ & $\begin{array}{c}\text { FLUEN } \\
\text { CY }\end{array}$ & $\begin{array}{c}\text { COMPREHEN } \\
\text { SION }\end{array}$ & $\begin{array}{c}\text { TOT } \\
\text { AL }\end{array}$ & $\begin{array}{c}\text { STUDE } \\
\text { NTS } \\
\text { SCORE }\end{array}$ & $\begin{array}{c}\text { SCORE } \\
\text { CLASSIFIC } \\
\text { ATION }\end{array}$ \\
\hline 1 & 3 & 4 & 4 & 11 & 61 & Poor \\
\hline 2 & 4 & 5 & 3 & 12 & 66.6 & Fair \\
\hline 3 & 4 & 4 & 5 & 13 & 72 & Fair \\
\hline 4 & 5 & 5 & 5 & 15 & 83 & Good \\
\hline 5 & 4 & 4 & 5 & 13 & 72 & Fair \\
\hline 6 & 5 & 5 & 5 & 15 & 83 & Good \\
\hline 7 & 5 & 5 & 6 & 16 & 88.8 & Very Good \\
\hline 8 & 5 & 4 & 5 & 14 & 77.7 & Good \\
\hline
\end{tabular}




\begin{tabular}{||c|c|c|c|c|c|c||}
\hline 9 & 4 & 5 & 5 & 14 & 77.7 & Good \\
\hline 10 & 5 & 5 & 5 & 15 & 83 & Good \\
\hline 11 & 4 & 5 & 5 & 14 & 77.7 & Good \\
\hline 12 & 4 & 4 & 5 & 13 & 72 & Fair \\
\hline 13 & 5 & 5 & 5 & 15 & 83 & Good \\
\hline 14 & 5 & 5 & 5 & 15 & 83 & Good \\
\hline 15 & 5 & 5 & 5 & 15 & 83 & Good \\
\hline 16 & 5 & 5 & 6 & 16 & 88.8 & Very Good \\
\hline Total & $\mathbf{7 2}$ & $\mathbf{7 5}$ & $\mathbf{7 9}$ & $\mathbf{2 2 6}$ & $\mathbf{1 2 5 2 . 3}$ & \\
\hline
\end{tabular}

Source : SMPN 2 Saluputti

Table 3 shows that the total score of the students in post-test was 226 and their total mean score was 1252.3. To find out the mean score of speaking ability of students. The following formula was applied:

$$
\begin{aligned}
& \quad \bar{X}=\frac{\sum X}{n} \\
& \quad \text { Where: } \\
& \sum x=1252.3 \\
& \mathrm{~N}=16 \\
& X=\frac{-}{X=78.2} \\
& \text { students' mean score was } 78.2
\end{aligned}
$$

Table 4: The classification, frequency, and percentage of the students' score in post- test

\begin{tabular}{|c|c|c|c|c|}
\hline Number & Classification & Score & Frequency & Percentage(\%) \\
\hline 1 & Very Good & $85-100$ & 2 & 13 \\
2 & Good & $75-84$ & 9 & 56 \\
3 & Fair & $65-74$ & 4 & 25 \\
4 & Poor & $55-64$ & 1 & 6 \\
5 & Very Poor & $0-54$ & - & - \\
\hline & Total & & $\mathbf{1 6}$ & $\mathbf{1 0 0}$ \\
\hline
\end{tabular}


In the post test there were 2 students or $13 \%$ of the sample classified as very good in post-test. There were 9 students or $56 \%$ of the sample classified as good. There were 4 students or $25 \%$ of the sample classified as fair. There was only 1 student or $6 \%$ of the sample classified as poor. There were no students $0 \%$ who got very poor classification. That means most of the students (56\%) classified as good classification.

In page 34-38 the researcher attached instrument of the research, research license and research recommendation to provide information to the reader what has been studied and whether the researcher actually examined.

\section{DISCUSSION}

In the result of the finding above shows there was different percentage in pretest and post- test of the students' ability in speaking for the eighth year students of SMPN 2 Saluputti. In pre- test, there were 16 or $100 \%$ students classified as "very poor" score, and in the post- test, there were 2 students or $13 \%$ of the sample classified as very good in post-test. There were 9 students or $56 \%$ of the sample classified as good. There were 4 students or $25 \%$ of the sample classified as fair. There was only 1 student or $6 \%$ of the sample classified as poor. The mean score of the students in the pre- test was 22.8 and the post- test was 78.2. The gain score was 55.3 (78.2> 22.8). It shows that the mean score of the post- test is greater than the pre test.

From the result of data analysis, it can be concluded that using small groups discussion can improve students' speaking ability for the eighth year students of SMPN 2 Saluputti.

The use of small groups discussion teaching strategy gives the students a lot of benefit, such as they have much opportunity to speak or express their ideas. It means that hypothesis is accepted.

\section{CONCLUSION AND SUGGESTION}

Based on the result of the research, the writer makes conclude, that the small groups discussion as a teaching strategy can improve the speaking ability of the students. It shows in post- test is greater than pre- test $(78.2>22.8)$.

It has been proven that Small Groups Discussion strategy can increase the activity and student learning outcomes in speaking subject, then the writer suggests the following things.

1. In teaching and learning activities teachers are expected to make cooperative learning as an alternative type of Small Groups Discussion in speaking subject to increase the activity and student learning outcomes.

2. Because this activity is very useful especially for teachers and students, it is expected that this activity can be done as class action research out continuously in speaking subject or another lesson. 


\section{REFERENCES}

Ali, Marwati. 2007. Stimulating the Ability of the Third Year Students at SMP Kristen Kandora to Speak English by Using Interesting Topics. Thesis S1 Pendidikan. Universitas Kristen Indonesia Toraja.

Brown, D. 1979. Principle of Language Learning and Teaching. New Jersey: Printice Hall. Inc

Byrne, D. 1980. Group Work in Language Teaching: Perspective. London: Longman. Chastain, Kenneth. 1976. Theory to Practice Developing Second Language Skill. Chicago: Rand-Mac Hally.

Clark, L. H. and Starr, L.S. 1981. Secondary and Middle Scholl Teaching Method. New York: Mc. Milan Publisher Co.Inc.

Depdikbud, 1985. Petunjuk Pelaksanaan Proses Belajar dan Petunjuk Pelaksanaan System Penelitian. Jakarta: Depdikbud

Freeman, Larsen, Diane. 1986. Technique and Principles in Language Teaching. Oxford: Oxford University Press.

Gafur, Abdul Syam. 2003. Increasing the speaking ability of English Conversation circle (ECC) members of English department of UNM through Australian Parliamentary Debate. Thesis, FBS UNM.

Gay L. R. 2006. Educational Research. New York: Charles Merill Publishing Co. And howell Company.

Harmer, Jeremy. 1991. Teaching English through English. Hongkong: Longman Groups (FE) Itd.

Harmer, Jeremy. 2004. The Practice of English Language Teaching. Third Edition. Malaysia: Longman

Harris, D. P. 1969. Testing English as a Second Language. Mcgraw. Hill inc.

Heaton, J.B. 1988. Writing English Test. New York: Longman Group UK Company.

Holden, S. 1981. Drama in Language Teaching. Longman Handbook for Teacher. Essex. Longman Group Limited.

Jabu, Baso. 2008. English Language Testing. Makassar: The UNM Publisher.

Lado, R. 1961. Language Testing. The Construction Use of Foreign Language Test. London: Longman Group.

Longman New Universal Dictionary. 1982.

McGreal, Rory. 1989. Copying Work and Language Learning. English Teaching Forum. Volume XXVII No.2 April 1989.

Pulston, C.B. and Bruder, M.N. 1976. Teaching English as a Second Language: Technique and Procedure. Toronto: Little Brown Company.

Rocks, G. 1981. The Non Stop Discussion Workbook Problem for Intermediate and Advanced Students of English. London: Newbury House Publisher Inc.

Simon, 1972. Value Clarification: A hand of Practical Strategies for Teacher and Students. New York: Hard Publishing.

Skinner, C. 1958. Essential for Education Psychology. New York: Practice Hall.

Sudjana. 1992. Metode Statistika. Bandung: Penerbit Tarsito Bandung. 
Tarigan, H.G.1988. Berbicara Sebagai Suatu Keterampilan Berbahasa. Bandung: Penerbit Angkasa.

Yulistha. 2009. Developing Student's Speaking Ability Through Group Discussion to the Second Year Students of SMK Ignatius Makale. Thesis S1 Pendidikan. Universitas Kristen Indonesia Toraja. 